\title{
Kuluttajapotentiaalia myymässä: Kuluttajatypologiat MTV:n mainosmyynnissä 1990-luvulla
}

\begin{abstract}
Miten tavaratuotanto ja tuotteiden mainonta vaikuttavat televisiotuotantoon? Kaupallisen television ansaintalogiikka on kaksivaiheinen: televisio tuottaa sisältöjä houkuttelemaan katsojia, joita se myy mainostajalle tuotteiden potentiaalisina kuluttajina. Tässä mediahistoriallisessa artikkelissa analysoidaan, miten ja mitä MTV myy mainostajille eli miten kuluttajaa määritellään ja arvotetaan myytävänä tuotteena. MTV rakensi 1990-luvulla mainosmyynnissään yleisöstä tuotteita luokittelemalla heitä erilaisiksi segmenteiksi ja kuluttajatyypeiksi. MTV:n mainostajille ja mainostoimistoille suunnattuja Media Manager -mediaoppaita ja tutkimusjulkaisuja analysoidessani havaitsin aineistosta arvoja ja ihanteita 1990-luvun kulutuskulttuurista. Kuluttaja alettiin nähdä entistä yksilöidympänä massa-ajattelun sijaan, kun yksilökeskeisyyden arvo nousi kilpailutalouden ja uusliberalistisen ideologian myötä.

Analyysini tuloksena havaitsin, että kiinnostavimpia kohderyhmiä yhdistivät 1990-luvulla hyvän ostovoiman lisäksi nuoruus, edelläkävijyys ja aktiivisuus. Brändien ja nuorten kohderyhmän nousu kytkeytyvät globalisoituvaan halpatuotantoon, jossa tuotteita myydään myös immateriaalista arvoa tuottamaan elämäntavan ilmaisemiseksi. Katsojien rakentaminen myytäviksi tuotteiksi asettaa kuluttajien maun ja elämäntyylit tiettyihin markkinoinnin tarkoituksiin sopiviin ja kulutusvalintojen määrittämiin kategorioihin, jotka rakentavat kulutusyhteiskunnan valtarakenteita.
\end{abstract}

AVAINSANAT: televisio, televisiotuotanto, MTV, mainonta, markkinointi, mediahistoria, kuluttajatypologia, brändi, kohderyhmät

aupallisen television ansaintalogiikka hahmottuu kaksivaiheisesti. Ensinnäkin televisio tuottaa sisältöjä houkuttelemaan katsojia, joita se sitten myy mainostajalle tuotteiden potentiaalisina kuluttajina. Kaupallisessa mediataloudessa yleisöt siis myydään mainostajille samalla, kun yleisöt ovat mediayritysten tuotteiden kuluttajia (ks. esim. Fiske 1987; Ang 1991; Napoli 2003). MTV' tarjoaa pääkanaviensa sisältöä ilmaiseksi katsojille, joita se myy katsojatutkimukseen perustuen katsojakontakteina mainostajille. Katsojista tuotetaan mainostajaa kiinnostavia tuotteita tyypittelemällä yleisöjä mainostajaa kiinnostaviksi ryhmiksi. "[J]okainen ohjelmatyyppi toimii porttina erilaisten ihmisten omiin maailmoihin. Laajan, monipuolisen ohjelmistonsa kautta MTV tarjoaa suuren määrän 'medioita mediassa' erilaisille kohderyhmille - jotka sinä ja me yhteistyössä myös tunnemme pintaa syvem- 
mältä." (MTV1990, TYK, 3.) Kaupallisen television on kyettävä kokoamaan mainostajia kiinnostavia yleisöjä ja luomaan mainoksille sopiva ohjelmaympäristö. Mediayhtiölle menestyksekäs kaupallinen toiminta perustuukin median kykyyn tarjota mainostajille niiden haluamia yleisöjä (Nieminen \& Pantti 2004, 91; Owen \& Wildman 1992, 3-5).

Tässä mediahistoriallisessa artikkelissa tarkastelen MTV:n mainosmyyntiä 199o-luvulla. Mediatutkimuksessa on tunnistettu yleisön merkitys myytävänä kauppatavarana jo pitkään. Philip M. Napoli toteaa kuitenkin, että viestintätutkimuksessa on usein jäänyt sivuun kuluttajan roolin taloudellinen analyysi, kun yleisötutkimuksessa on keskitytty todellisen yleisön tarkasteluun ja mediatalouden tutkijat puolestaan ovat keskittyneet mediayhtiöiden rooliin sisällöntuotannossa ja jakelussa sekä mediatalouden rakenteisiin. Napoli tekee tutkimuksessaan tärkeän erottelun ennustettuun, mitattuun ja todelliseen yleisöön, jolla hän kuvaa yleisön vaiheita kauppatavarana mediaorganisaatioiden, katsojatutkimusta tuottavien yritysten ja kuluttajien näkökulmasta (Napoli 2003). Myös omassa tutkimuksessani keskeistä on yleisön tuottamisen näkökulma - miten MTV mainosmyynnissään rakensi katsojatutkimuksen avulla ennustetusta ja mitatusta yleisöstä potentiaalisia kuluttajia mainostajalle luokittelemalla heitä erilaisiksi segmenteiksi ja kuluttajatyypeiksi (ks. kuvio 1). Nämä rakennetut kuluttajatyypit kertovat enemmän kuluttajiin liitetyistä arvoista ja ihanteista kuin "todellisesta" yleisöstä, joka jää artikkelini tarkastelun ulkopuolelle.

Kuvio 1. Myyntisuhteet MTV:n, mainostajan, todellisen yleisön ja kuutustutkimusta tekevien yritysten välillä. Myyntituotteina potentiaalinen ennustettu ja mitattu yleisö sekä mainostettavat tuotteet/ palvelut todelliselle yleisölle.
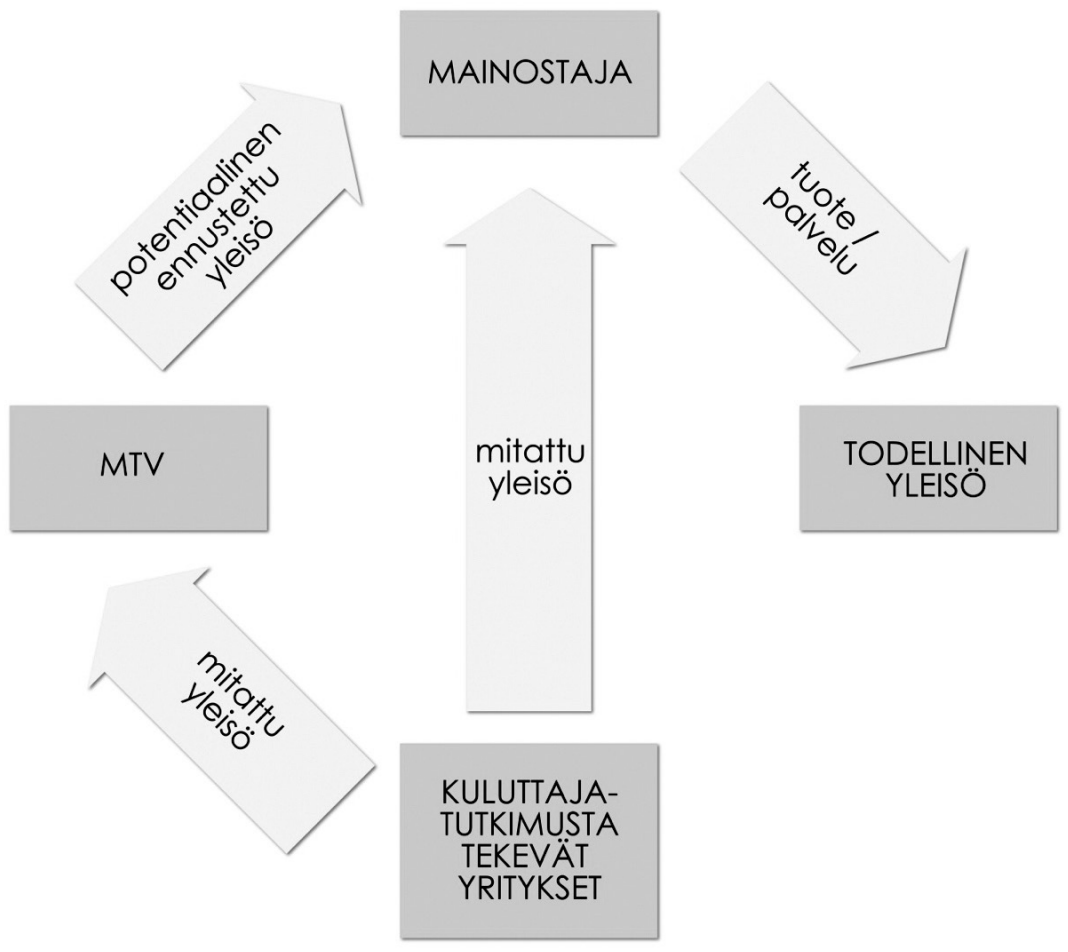
MTV:n kauppatavarana oli mitattu yleisö, jonka laatu taattiin tv-mittaritutkimuksen luotettavuudella. MTV:n mediaoppaassa todetaan, että "suoritevarmuus on mainostajalle tärkeä asia - se, että saa, mitä tilaa" (SyysManager 2000, TYK, 22). Suoritevarmuutta taattiin kehittämällä katsojatutkimusta, mainosmyynnin ehtoja ja mediatuotteita, kuten kontaktitakuujärjestelmä, jossa mainostajalle voitiin luvata kontaktien tavoittaminen kampanjassa tarvittaessa takuupaloilla. Mittaaminen muutti katsojat tuotteeksi, josta voitiin luokitteluilla rakentaa erilaisia edullisia paketteja ja jolle voitiin taata takuu, kuten mille tahansa tuotteille. Markkinoinnin diskurssissa kuluttaja sulautui tuotteeksi, jota tutkittiin, mitattiin ja myytiin ja jonka tuoteominaisuuksia voitiin kuvailla mainostajaa kiinnostavilla tavoilla.

Analysoin artikkelissa, miten ja mitä MTV myi mainostajille eli miten kuluttajaa määriteltiin ja arvotettiin myytävänä tuotteena mainostajille. Kun kuluttajasta rakennetaan tuote mainosmyyntiin, katsojien tyypittelyllä, erilaisilla luokitteluilla ja ihannepiirteiden kuvailuilla nostetaan jotkut yleisöt toisia arvokkaammiksi. Artikkelissa tarkastelen, minkälaisia käsityksiä ja arvoja kytkeytyi potentiaalisten kuluttajien tyypittelyihin ja diskursseihin MTV:n markkinoinnissa. Ymmärrän arvot historiallisesti ja kulttuurisesti rakentuneina; 1990-luvun mainosmyynnin arvot kertovat laajemmin yksilölle ja yhteiskunnalle sekä kulutukselle annetuista merkityksistä. Kuluttajille myydyt elämäntavat kuvaavat sosiaalista muutosta, erityisesti yksilöllistymistä (Miles 2000, 84). Mainonnassa arvot nähdään oleellisina kuluttajien toiminnassa valintoja ohjaamassa. Arvoista puhutaan sekä ihmisten että tuotteiden yhteydessä ja vahvassa brändissä kuluttajan ja tuotteen arvot kohtaavat (de Mooij 1998, 116). Keskityn kuluttajaluokittelujen muutokseen osana kaupallisen television 1990-luvun tuotantokulttuuria. MTV sai oman kanavansa vuonna 1993 ja saavutti suuren katsoja- ja mainonnan markkinaosuuden, markkinoinnissa 1990-lukua luonnehditaan brändien vuosikymmeneksi.

Tarkastelujaksoni alkaa ja päättyy mainosmyynnin murroksiin 1980-luvun lopulta 2000-luvulle. Aloitan tarkasteluni 1980-luvun lopulta, jolloin laadulliset luokittelut yleisöstä alkoivat painottua määrään perustuvan mainostilan myynnin sijaan. Kun 1984 vuoden mainonnan tutkimuksen esittelyssä keskityttiin määrälliseen tutkimukseen mainosten huomioarvon, vaikuttavuuden ja katsojamäärien mittaamisessa (MTV 1984, TYK), vuonna 1989 esiteltiin Monitor-asennetutkimuksen tuomaa laadullista "pehmeää loppusilausta" (MTV 1989, TYK, 4). 1980-luvun lopulla tuli markkinointiin liittyen monia teknologisia uudistuksia, kuten sähköinen tv-mittaritutkimus ja atk-järjestelmien kehittyminen, joiden myötä kuluttajien entistä tarkempi tyypittely mahdollistui. MTV kilpaili tuolloin mainosmyynnissä niin lehdistön kuin juuri aloittaneiden Kolmoskanavan ja kaupallisten radioiden kanssa. 1990-luvun markkinoinnissa kuluttajien luokittelu kiinnittyi arvoihin, kun kuluttajat alettiin nähdä uudenlaisina itseään toteuttavina yksilöinä ja kulutus valintoina, joilla rakennetaan identiteettiä (ks. esim. Cronin (2005 [2000], 43; Puustinen 2008, 37). Myös vuosikymmenen alun lama ja voimistuva uusliberalismin ideologia korostivat ajatusta yksilön merkityksestä ja voimasta elämässä menestymisessä (Lind 2002, 347-348). Medioiden välinen kilpailu mainosrahoista koventui laman myötä ja vuonna 1997 
aloittanut Nelonen asetti MTV:n uudenlaisen kanavakilpailun eteen. Päätän tarkasteluni digitaalitelevision viralliseen käyttöönottoon vuonna 2001, jolloin Subtv aloitti MTV3:n rinnalla MTV:n toisena kanavana. Myös tv-mainonnassa alkoi tuolloin murros strategisen suunnittelun hajautuessa eri kanaville digitalisoinnin ja sen mahdollistaman maksu-tv:n myötä samalla kun mainostulojen lasku ja Internetin yleistyminen toivat mukanaan ansaintataloudellisia haasteita.

Markkinoinnissa kuluttajien asenteet ja arvot liitettiin vahvasti ostokäyttäytymisen vaikuttimiksi ja näin kuluttajien arvojen tutkimus ohjasi osaltaan MTV:n toimintaa. MTV hyödynsi mainosmyynnissään monenlaista kuluttajatutkimusta, jota tehtiin markkinointipäätösten perustaksi markkinoista, kilpailutilanteesta ja kuluttajien asenne- ja arvomaailmasta. Mediatalouden tärkeinä toimijoina mainostoimistojen ja mainostajien ohella olivat markkinointi- ja mediatutkimusta tekevät yritykset, joiden tutkimusta käyttivät monet mainos- ja mediayhtiöt, sanoma- ja aikakauslehdet, mainostajat ja televisioyhtiöt, kuten myös MTV. (Rope 1992, 11, 21-22; TT 1997.) Olen kiinnostunut siitä, miten tutkimuksia käytetään tutkittavalla ajanjaksolla osana MTV:n markkinointia. MTV:n mediaoppaissa perustellaan mainostajalle tutkimustietoon vedoten, miksi valita juuri televisio mainosmediaksi ja kuvaillaan haluttuja kohderyhmiä ja näiden tavoittamista eri mediatuotteilla.

Tutkimusaineistonani on MTV:n mainostajille ja mainostoimistoille suunnattuja Media Manager -mediaoppaita (MM) ja tutkimusjulkaisuja vuosilta 1989-2000, joissa esitellään mainostajalle erilaisia mediatuotteita ja mainostustapoja. Käytössäni on joka vuodelta vähintään yhden ohjelmakauden Media Manager -opas ja muita mainosmyyntiin liittyviä esitteitä ja tutkimuksia, joista kontekstoivalla lähiluvulla jäljitän muutoksia ja jatkuvuuksia mainosmyynnissä käytetyissä yleisön kategorioinneissa ja diskursseissa. Historiallinen aineistolähtöinen lähestymistapani nostaa esiin aineistosta katsojakontaktien myynnin teemoja. Mediatutkija Heidi Keinonen on kutsunut tätä historiantutkimuksessa usein esittelemättä jäävää metodia teemoittamiseksi. Aineistolähtöisessä analyysissa laajasta ja monimuotoisesta lähdeaineistosta paikannetaan tutkimusta merkityksellistäviä kohtia, joista ryhmitellään eri teemoihin liittyvät asiat (Keinonen 2011, 36, 42-44). Analyysissani merkityksellisiksi teemoiksi nousevat kuluttajaluokittelut ja -typologiat sekä brändit. Markkinointitutkimus ja mediaoppaat tutkimukseni aineistona paljastavat, minkälaista teoreettisia oletuksia tuolloin tehtiin mediataloudesta ja minkälaisiin tulkintoihin kuluttajista ne kutsuivat. Aineistoni avulla avaan suomalaisen television tutkimuksessa vähälle jääneen näkökulman kaupallisen television tuotantoon, joka kuvaa laajemmin kulutuskulttuurin muutosta 1990-luvulla. Hyödynnän mainonnan historian viestinnällistä tutkimusta. Esimerkiksi mainostoimistojen näkökulmaa kuluttajien luokittelussa hahmotan Liina Puustisen (2008) tutkimuksen avulla. Hän on analysoinut mainonnan ja markkinoinnin ammattilaisten tapoja luokitella kuluttajia haastatteluaineiston pohjalta. Kuluttajien luokittelun hän näkee diskursiivisena keinona, jolla markkinoijat pyrkivät kuluttajien hallintaan. 


\section{Kuluttajaryhmien luokittelu - massoista yksilökeskeisyyteen}

"Taloudellisen kasvun olennaisena osatekijänä joukkotuotanto on yleisesti hyväksytty. Se edellyttää kuitenkin jatkokseen massajakelua ja massatiedotustoimintaa, jonka tärkeä muoto mainonta on." (MTV 1968, 6.) Sitaatti MTV:n lausunnosta Yleisradion hallintoneuvostolle kiteyttää mainonnan merkityksen vielä 196o-luvulla massaviestinnäksi, jossa kuluttajat nähtiin mainosten passiivisina vastaanottajina. Tuotteiden tuotantotapa liittyy oleellisesti tuotteiden markkinointiin ja siten käsityksiin kuluttajasta. 1960-luvulla markkinoinnissa tapahtui kansainvälisesti kulttuurinen käänne, kun professionalisoitunut kuluttajatutkimus alkoi tietoteknistymisen avulla kerätä ja käsitellä suurta määrää kvalitatiivista dataa kuluttajista - kulutuskäyttäytymistä ei nähty enää vain luokan mukaan määräytyvänä (Arvidsson 2006, 42, 52-53). Voimakkaan talouskasvun ja -kilpailun aikaan 1980-luvulla kulutushyödykkeiden hintojen laskun ja elintason nousun myötä markkinoinnissa alettiin puhua yhä enemmän yksilöllisistä ja aktiivisista kuluttajista. Tarkastelen nyt kuluttajien luokittelun muutosta 1980-luvun lopulta 1990-luvun loppuun, jolloin MTV:Ilä siirryttiin kuluttajien määrällisestä myynnistä laadulliseen, tarkasti kuvailtujen kohderyhmien myyntiin.

Tuotesuunnittelun ja mainonnan hallitsevaksi strategiaksi tuli 1960-luvun puolestavälistä lähtien kohdistaminen erityisiin kohderyhmiin eli valikoiva mainonta (Partanen \& Ilmonen 1980, 84). Yleisön tyypittelyssä demografinen luokittelu iän, sukupuolen, sosiaaliryhmän, tulotason ja asuinpaikan mukaan otettiin käyttöön jo 1950-luvulla englantilaisissa markkinointitutkimuksissa. Myös MTV hyödynsi mainosmyynnissään omaa ja muiden markkinointitutkimusta tekevien organisaatioiden katsojatutkimusta jo 1960-luvulla. Mainosmyynti säilyi kuitenkin määrällisenä vuoteen 1989 asti; vaikka katsojatutkimuksella luokiteltiin kuluttajia demografisesti, mainosaika myytiin kontaktiryhmän koon tai alueen mukaan. Mainosajan sijoittelulla mainostaja saattoi kohdentaa tuotettaan halutulle kohderyhmälle: MTV:n viestintäraportissa vuodelta 1978 todetaan, että "perinteellisesti ohjelmien valinta tvkampanjaa varten on tapahtunut etsimällä ohjelmia, joiden demografiset profiilit vastaavat mahdollisimman hyvin mainostettavan tuotteen käyttäjäprofilia" (Kasari $1978,15)$.

Demografinen luokittelu sai 1980-luvun puolivälissä osakseen kasvavaa arvostelua, koska yhteiskunnan katsottiin muuttuneen niin paljon, ettei luokittelulla ollut enää merkitystä. Segmentointia lähdettiin kehittämään yhdistämällä demografisia luokitteluja uudella tavalla tai kokonaan uusilla luokitteluilla, esimerkiksi elämäntyyliin pohjautuen. Myös kuluttajatutkimuksen teknologinen kehitys mahdollisti luokittelujen uudenlaisen rakentamisen. Suomessa otettiin 1987 käyttöön kaikkien kanavien yhteinen Finnpanelin sähköinen tv-mittaritutkimus, jonka perusaineistoa voitiin tietokoneella käsitellä yhdistämällä erilaisia demografiamuuttujia. (Kasari 1988, 52-53.) Sähköinen mittaritutkimus ja atk-järjestelmien kehittyminen mahdollistivat myös reaaliaikaisemmat yliyön raportit ohjelmien katsojista, minkä seurauksena MTV pystyi tarjoamaan mainostajalle vuodesta 1989 kontaktitakuun. "MTV 
on ainoa mainosväline, josta saat yleisten peitto- ja levikkilukujen sijaan varman, ohjelma- ja kampanjakohtaisesti tutkitun vastikkeen mainospanostuksillesi" (MM kevät 1991, TYK). Kontaktitakuu tarkoitti, että katsojamittausjärjestelmästä pystyttiin tarkistamaan toteutuneet katsojamäärät ennen kampanjan päättymistä ja siten varmistamaan kaikkien luvattujen kontaktien tavoittaminen. Näin väli kauppatavarana olevan ennustetun yleisön ja mitatun yleisön välillä pieneni.

Markkinoinnin teoriassa segmentoinnilla tarkoitetaan kokonaismarkkinoiden jakamista suhteellisen homogeenisiin ryhmiin. Jakoa voidaan tehdä alueellisin, demografisin, psykografisin tai käyttäytymisen perustein. Alueellinen mainonta jakoi television antennitalouksien katsojakuntaa ensimmäistä kertaa erikseen myytäviin segmentteihin. Viestintätutkija Heikki Hellmanin mukaan Kolmostelevisio toi Suomeen alueellisen mainonnan, joka muutti tv-mainonnan luonnetta ja lisäsi niin ilmoittajien kuin mainonnankin määrää, kun tuotteita oli mahdollista myydä halutulla alueella. Alueellisen päivittäistavarailmoittelun myötä televisio alkoi kilpailla ilmoittajista ykköslehtien kanssa (Hellman 2012, 266-267). Kauppa keskittyi 1980-luvulla suuriin marketteihin, kun alalle syntyi neljä suurta kilpailevaa keskusliikettä: S-, E-, K- ja T-ryhmä. Tarjouskauppa ja -ilmoittelu lisääntyivät, mikä vaikutti myös alueelliseen televisiomainontaan positiivisesti. 1990-luvun alun lama kiristi mainosmarkkinat, kun mainonnan investoinnit laskivat rajusti. (Heinonen \& Konttinen 2001, 211-213.) Televisio onnistui kuitenkin kasvattamaan mainososuuttaan ohjelmatarjonnan lisääntymisen ja hintajoustavuuden ansiosta; MTV:n osuus mainosmarkkinoista lähes kaksinkertaistui 1988-1993 lehdistön kokiessa suuret tappiot (Hellman 2012, 341-342). 1990-luvun lopun vuodet olivat vaikeita televisiomainonnalle, eivätkä suuret odotukset ja kasvulaskelmat toteutuneet, vaan kasvu taantui ja painettu mainonta säilytti asemansa suurimpana. Lisäksi Internet-mainonta tuli uutena mainosmediana haastamaan television asemaa. Vuonna 1990 televisiomainonnan osuus oli 14 prosenttia mediamainonnasta, huippuvuosina 1995-1997 osuus oli 22 prosenttia ja vuonna 2000 se tippui 19 prosenttiin (LVM 26/2002, 23, 26, 45).

Konkreettisten demografisten luokittelujen rinnalle kehitettiin laadullisilla menetelmillä selvitettyjä psykografisia muuttujia 1970-luvulla. Psykografisina muuttujina eroteltiin elämänvaihe, elämäntapa ja persoonallisuus, asenteet ja arvot. Markkinoinnissa psykografiset luokittelut nähtiin muuttuvampina, mikä oli vastaus dynaamiseksi koettuun sosiaaliseen ympäristöön (Arvidsson 2006, 61). Yhteiskuntatieteissä yleisesti elämäntapatutkimus nousi keskeiseksi tutkimusalaksi, jota hyödynnettiin myös televisiotoiminnassa, Yleisradiossa ja MTV:Ilä (ks. Allardt 1986). Markkinoinnissa kohderyhmiä ei enää nähty massoista koostuvina segmentteinä vaan enemmän yksilöinä, joiden psykologisia ostomotiiveja pyrittiin selvittämään. Yksinkertaistetuilla kuluttajakategorioilla pyrittiin tekemään kuluttajaryhmistä hallittavia, persoonallisilla piirteillä kuvailtavia tyyppejä. (Puustinen 2008, 88-91.) MTV:n mainosmyynnissä kuluttajien demografiset muuttujat säilyivät oleellisina kuluttajia määrittelevinä luokitteluina koko 1990-luvun. Keskeisimmät luokittelut tehtiin iän, sukupuolen, kaupunkiasumisen, ammattiryhmän ja per- 
hekoon pohjalta. Personoidumpia kuluttajatyyppejä alettiin tuottaa MTV:Ilä Monitor-asenne- ja elämäntyylitutkimukseen pohjautuen 1990-luvun alussa.

MTV oli käyttänyt Marketing Radar Oy:n toteuttamaa monikansallista Monitortutkimusta jo vuodesta 1975 alkaen, mutta vuonna 1989 se yhdistettiin tv-mittaritutkimukseen, jolloin tutkimus tuli myös ohjelmatoiminnan ja mainostajien käyttöön. Monitorin käyttö mahdollisti kampanjan tarkemman kohdentamisen ja antoi mahdollisuuden seurata heti yliyönraporteista, miten eri ohjelmat sijoittuivat Monitor-ryhmiin ja tavoittivat ryhmien katsojakuntia. (Vuosikertomus 1989, TÄK, 6; MM syksy 1991, TYK, 3.) Teknologinen kehitys mahdollisti tarkemmat ja nopeammat analyysit kohderyhmistä, millä MTV vetosi mainostajiin: "Pieni, mutta tärkeä yksityiskohta on juuri käyttöönottamamme Amiga-mikrotietokone. Marketing Radarin meille toimittaman ohjelmiston ja aineiston avulla voimme nyt analysoida kohderyhmiä itse. Tehokkaasti, joustavasti ja nopeasti." (MTV 1990a, TYK, 5.) Tietokoneen avulla satojen muuttujien klustereista voitiin rakentaa teoreettisia elämäntyylejä (Arvidsson 2006, 60). Vuonna 1999 MTV3 siirtyi asenne- ja arvotypologioiden käytössä Monitor-tutkimuksesta RISCiin, jossa painotettiin arvo- ja asenneluokittelua sosiograafisten piirteiden sijaan (Tutkimus 1999, TYK, 3). MTV:Ilä keskeisen sijan sai RISCissä kehitelty kymmenluokkainen ACE ja siitä pelkistetty neliluokkainen asennetypologia: vastuuntuntoiset, kokeilijat, vakiintuneet ja statussuuntautuneet (Tutkimus 2000, TYK, 30). Brändejä tutkinut Adam Arvidsson kuvaa muutosta, kuinka yksittäisistä kuluttajista rakentui datapilviä, joissa yhdistyi kulutusta edustavia representaatioita - huomio siirtyi yksilön todellisesta kulutuksesta sosiaalisiin saavutuksiin ja arvojen abstraktioihin eli immateriaaliseen pääomaan (Arvidsson 2006, 64-65).

MTV myi mainostajalle tätä immateriaalista pääomaa rakennettuina kuluttajatypologioina. MTV mainosti mainostajille Monitor-tutkimusta apuna kohderyhmäanalyysissa, keinona tuntea kuluttajat ja ymmärtää heitä syvemmin. "Monitor-tutkimuksen perusteella me kerromme, millaisia suomalaiset television katsojat ovat, miten he katsovat televisiota ja millainen mainonta puhuttelee heitä" (MTV 1990a, TYK, 3). Tutkimuksessa selvitettiin ihmisten perusasenteiden lisäksi laajasti kulutusja mediakäyttäytymiseen liittyviä asioita keräämällä kvalitatiivista ja kvantitatiivista kyselytietoa. Tutkimuksen perusteella muodostettiin 12 sosiografista ryhmää, viisi kuluttajatypologiaa ja viisi omaksujatyyppiä (MTV 1990a, TYK, 4). 1990-luvulla MTV:n käytössä olleet keskeiset Monitor-typologiat olivat: nautiskelevat materialistit, rationaaliset materialistit, empaattiset riskinottajat, itseään toteuttavat luontoihmiset ja turvallisuushakuiset perheihmiset. Typologiat asettuivat Monitortutkijoiden tulkintaan asenneavaruuden perusdimensioista [ks. kuva 1]. Ryhmien demografisina piirteinä eriteltiin tiettyä ikäryhmää, sukupuolta ja toimihenkilöiden osuutta. (MTV 1990a, TYK, 8-17; MTV 1992, TYK, 11.) Typologioita kuvailtiin esimerkkihenkilöiden avulla, joiden persoonaa kuvailtiin suhteessa kulutukseen, elämänarvoihin, televisionkatseluun ja mainontaan. 
Kuva 1. Monitor-tutkimuksen asennekarttaan sijoittuneet typologiaryhmät: nautiskelevat materialistit (A), rationaaliset materialistit (B), empaattiset riskinottajat (C), itseään toteuttavat luontoihmiset (D) ja turvallisuushakuiset perheihmiset (E) (MTV 1990a, 6).
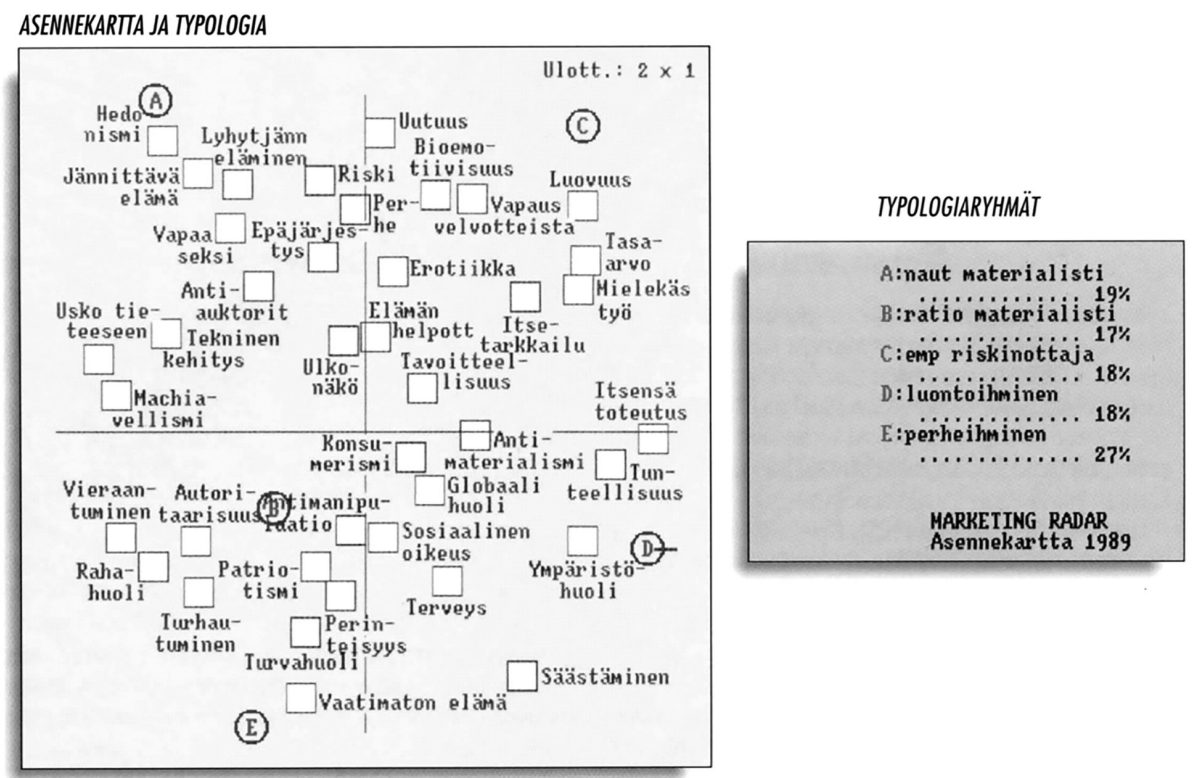

Monitor-typologioiden ryhmien kerrotaan kattavan koko väestön, mutta kuvauksissa painottuvat hyvä asema ja toimeentulo työelämässä sekä korkea koulutus (MTV 1990a). Vuoden 1992 Media Manager -oppaan typologioiden tiiviissä kuvauksissa määritetään hahmoille myös tarkat iät ja ammatit. Nautiskeleva materialisti on nuori, aktiivinen, koulutettu Kimmo, joka nauttii elämästä ja kuluttaa uusiin harrastuksiin huolettomasti (MTV 1990a, TYK, 8-9). Hän voisi olla myös 24-vuotias Jan perustamassa tietotekniikka-alan yritystä kavereiden kanssa (MM 1 1992, TYK, 11). Empaattinen riskinottaja on nuori ja aktiivinen Sari, joka on osannut ottaa ilon irti elämästä, mutta on kuitenkin tehokas ja työelämässään jo menestynyt, arvostaa laatua ja kalliita tuotteita (MTV 1990a, 10-11). Hän voisi olla myös Marika 32-vuotta, tuotepäällikkö (MM 1 1992, TYK, 11). Rationaalinen materialisti on vanhempi avioitunut, "raavas mies" Jarmo, jolla on jo hyvä auto ja kunnon kesämökki ja joka kuluttaa järkevästi (MTV 1990a, TYK, 12-13). Hän voisi olla myös 40-vuotias Reijo, tuotepäällikkö (MM 1 1992, TYK, 11). Itseään toteuttava luontoihminen on ystävien kanssa viihtyvä vanhempi Marjut, jolle raha ei ole itseisarvo, mutta joka kuluttaa mielellään itseensä, esimerkiksi lomamatkoihin (MTV 1990a, TYK, 14-15). Hän voisi olla myös 36-vuotias Virve, tutkimuspäällikkö, joka viimeistelee väitöskirjaansa (MM 1 1992, TYK, 11). Turvallisuushakuinen perheihminen on kotona ja työpaikallaan ahkera puurtaja, perheenäiti, "pikku vaimo" Mirja, jolla on varma toimeentulo ja joka kuluttaa kotiin ja perheeseen (MTV 1990a, TYK, 16-17). Hän voisi olla myös Terttu, 50 vuotta, konttoristi (MM 1 1992, TYK, 11). 
Monitor-typologioiden esimerkkihenkilöiden kuvauksiin ei mahdu köyhyyttä, sairautta tai mitään elämän negatiivisuutta vaan ainoastaan eri tavoin menestyneitä ja kulutussuuntautuneita tyyppejä. Kuluttajatyyppien nimillä ja luonnehdinnoilla pyritään luomaan mielikuvaa mainostajalle haluttavasta kohderyhmästä. Kuluttajatyypeissä voi nähdä yhteyden myös 1980-luvun mainoksissa korostuneeseen uuteen ihmistyyppiin: nuorekkaaseen ja menevään juppiin (Heinonen \& Konttinen 2001, 272, 307). Vastaavasti historioitsija Merja Lind havaitsi menestyneen yksilön kuvauksien korostumisen tutkiessaan Image-lehden näkemyksiä yksilöstä 1990-luvun lamavuosina ja niiden jälkeen. Kiihkeän voitontahtoinen yksilö oli tuolloin yhteiskunnan kannalta hyvä malli, koska se korosti yksilön oman suorittamisen merkitystä ja käänsi huomion pois yhteiskunnan velvollisuuksista yksilöä kohtaan. Uusliberalistisen markkinaideologian mukaisesti yksilön oma vastuu menestyksestään jätti huomiotta heikot ja sairaat, jotka eivät kykene taistelemaan menestyksestään. (Lind 2002, 348.)

Vuodesta 1990 vuoteen 1993 mainosmyynnissä mediatuotteina olivat Monitor-tutkimukseen pohjautuvat MTV-Packit: youngpack nuorille, citypack "vitaalien nuorten aikuisten" ja "elämännälkäisten kokijoiden" tavoittamiseen, businesspack tavoittamaan yritysjohtajan vapaalla, familypack uutuuksille ahneelle laajalle lapsiperheiden joukolle ja lisäksi sportspack urheilua seuraaville (MM kevät 1990, TYK, 10-15). Kullekin ryhmälle valittiin sopivia ohjelmia, jotka sijoittuivat Monitor-akselien perusteella yhteen ryhmien kanssa. Näin "MTV-Packit [---] muodostavat ohjelmaympäristöt, joiden äärestä eri kohderyhmät aidoimmillaan tavoittaa ja joissa tuotteen ja kuluttajan yhteensaattaminen luontevimmin käy päinsä" (MM kevät 1990, TYK, 10). Esimerkiksi maanantain ohjelmistosta ulkomainen pitkä elokuva listattiin sekä youngpackin että citypackin ohjelmaksi, businesspackille Kymmenen Uutiset ja familypackille viihdettä, kuten Levyraati, Vesku Show ja sketsisarja Paha yskä (MM kevät 1990, TYK, 10-14). Vuonna 1993 edellisiä täydensivät greenpack "modernien, uusia vihertäviä ajatuksia omaksuneiden suomalaisten tavoittamiseen" ja seniorpack iäkkäämpien suuryleisöjen tavoittamiseen (MM kevät 1993, TYK, 19-20).

Greenpack-kohderyhmän ja itseään toteuttavan luontoihmisen Monitor-typologian voi nähdä liittyvän vihreän kulutuksen ajatuksen nousuun 1990-luvun alussa. MTV:n yhdistäessä Monitor-asennetutkimuksen ja tv-mittaritutkimuksen vuodenvaihteessa 1991 apulaisjohtaja Markku Takanen totesi, että "[p]erinteiset arvot ja vihreys näyttävät olevan kasvussa" (MM syksy 1991, TYK, 3). MTV:n kohderyhmänä greenpackista ja itseään toteuttavista luontoihmisistä tehtiin vetoava kohderyhmä kuvailemalla heitä moderneiksi, uusista tuotteista kiinnostuneiksi. Kestävän kehityksen mahdollisuuksiin yhdistettiinkin 1990-luvun alussa teknologiaoptimismi kestävän tietoyhteiskuntavision muodossa (Autio \& Wilska 2003, 3). Vihreys näyttäytyi tuolloin edelläkävijyytenä. Greenpack-kohderyhmäpaketti oli yhdistelmä Monitor-typologioista empaattiset riskinottajat ja itseään toteuttavat luontoihmiset (kohderyhmän koko 1.373.000), joten sillä ei viitattu mihinkään kapeaan erityisryhmään, kuten ympäristöaktivisteihin. Organisaatioviestinnän tutkija Johanna Moisanderin mukaan yleinen mielikuva vihreästä kuluttajasta oli vielä vuosituhannen vaihteessa harmaa, puritaaninen ja ankea: vihreä kuluttaja kieltäytyi kauniista, mielihyvästä ja iloista, jolloin heistä oli vaikeaa 
rakentaa vetävää brändiä ja mainostajia houkuttavaa kohderyhmää (Moisander 2001). MTV:n kohderyhmämäärittelyihin vihreät arvot tulivat siis jo verrattain varhain ennen laajempaa käsitysten muutosta, mikä kertoo siitä, kuinka tärkeitä nousevat arvot ja edelläkävijyys olivat kohderyhmämäärittelyissä. Greenpack-kohderyhmänimenä ei kuitenkaan säilynyt pitkään, vaikkakin vastuullisuus ja luonnon arvostaminen säilyivät asenteina Monitor-typologiassa itseään toteuttavat luontoihmiset.

Kuten Moisander huomauttaa, vihreän kuluttajan käsitteeseen liittyi tiiviisti oletus siitä, että yksittäisen ihmisen kulutusvalinnoilla olisi suuri merkitys. Ympäristöarvojen ja vastuullisen kuluttamisen painotus korosti kuluttajien saamaa markkinavaltaa ja yksilökeskeisyyttä. (Moisander 2001.) Markkinoinnissa käännyttiinkin 199o-luvun alussa kohti yksittäisten kuluttajien sisäistä maailmaa: "Sisäisten arvojen lisääntyvä korostuminen on todellinen haaste yrityksille. - Toisaalta syvällisempi elämänasenne antaa nyt ennen kokemattomia mahdollisuuksia 'aineettomien' tuotteiden ja palveluiden kuten kulttuurin markkinoille." (MTV 1990a, TYK, 4.) Kuluttajan vastuullisuus ja vihreiden arvojen nousu käännettiin MTV:n markkinoinnissa positiiviseksi mahdollisuudeksi mainostajille: "[L]isääntyvä huoli kehityksen rakenteellisesta suunnasta tarjoaa puolestaan mahdollisuudet yhteiskunnallisten teemojen kampanjoinnille. Ihmisten vastuuseen ja omaantuntoon vetoaminen tuottaa positiivisen palautteen." (MTV 1990a, TYK, 4.)

Sekä kuluttajan vastuu että kuluttajatypologioiden kuvaaminen persoonallisina yksilöinä kytkeytyy yksilökeskeisyyden arvon nousuun 1990-luvulla. Arvoina yksilökeskeisyys ja markkinavoimien roolin korostaminen menestyksen kuvauksissa liittyivät kilpailutalouteen, johon Suomi alkoi siirtyä 1980-luvun alussa suunnitelmatalouden jälkeen. Valtio purki säännöstelyjä monella alalla, muun muassa viestinnässä, mainonnassa ja pankkijärjestelmässä (Nieminen \& Pantti 2004, 39-40). Sekä Yleisradio että MTV siirtyivät strategioissaan asiakaslähtöisyyteen, kun television poliittisesti säädellystä kilpailuympäristöstä siirryttiin liberaaliin kilpailuun (Hujanen 2002, 118). 1990-luvun lopun Monitor-asennetutkimus kertoi suomalaisten yksilökeskeisyyden voimistuneen ja kohderyhmien pirstaloituneen - demografiset ryhmät esitettiin sisäisesti entistä hajanaisempina ja eriytyneempinä (Heinonen \& Konttinen 2001, 211-215, 299). Yksilöllisyyden arvon korostaminen problematisoi kuluttajien luokittelua yhtenäisiksi ryhmiksi.

Kuluttajien aktiivisuus nousi myös esiin uusien teknologioiden mahdollistamana 1990-luvulla. Katsojalle kehitettiin osallistumismahdollisuuksia, kuten MTV-Palautepalvelu, jonka avulla "katsoja voi reagoida näkemäänsä tv-mainokseen välittömästi" puhelimitse (MM kevät 1992, TYK, 20). Interaktiivisuus nousi tärkeäksi markkinointivaltiksi, johon liittyen kehitettiin 1990-luvun puolivälissä useita palveluita: teksti-tv, infomercial, Ostoskanava. Uusien palvelujen avulla MTV halusi tarjota mainostajalle suoraa vuorovaikutusta kuluttajan kanssa: "[e]nää ei tarvitse tyytyä yksisuuntaiseen informaatioon mainostajalta asiakkaalle, vaan nyt on mahdollista saada asiakkaan palaute välittömänä ja täsmällisenä" (MM kevät 1994, TYK, 12). 1990-luvun puolivälin mediaoppaissa näkyy teknologinen visiointi interaktiivisuuden ympärillä, joka laantui 2000-luvulle tultaessa. Teknologinen kehitys tarjosi uusia mahdollisuuksia televi- 
siomainonnassa, joihin liitettiin myös voimakkaita visioita. Hannu Salmi on tutkinut tietoyhteiskuntakeskustelua 1990-luvun laman aikaan ja hänen tulkintansa mukaan innovaatio nousi teknokielen lempikäsitteeksi talouskriisin jälkeisessä Suomessa, kun innovaatioiden kehittäminen nostettiin tavoitteeksi lamasta selviytymiseen (Salmi 2002, 332-338). Internetin vakiintuminen keskitti MTV:n interaktiivisuuteen liittyvää kehitystä ja mainontaa sinne ja vähensi televisioon liittyviä palveluja, kuten teksti-tv:n interaktiivisia ominaisuuksia.

Kyse oli entistä laajemmin kuluttajan ymmärtämisen muutoksesta, massa-ajattelusta kohti yksilöidympää kuluttajaa. MTV:Ilä siirtymä massoista kohdeyleisöihin ei ollut yksiviivainen, vaan mainostajalle tarjottiin valinnanvaraa: "Valitsetko massakampanjan ja miljoonakontaktit vai tarkat kohderyhmäkontaktit?" (MTV 199ob, TYK, 4). Mainostajan, mainonnan käytäntöjen ja yhteiskuntatieteellisen kulutustutkimuksen käsitykset kuluttajasta kulkevat käsi kädessä, tutkimuksen ja mainonnan diskurssit ovat vuorovaikutuksessa keskenään. Marxilaisessa kulutustutkimuksessa, etenkin Frankfurtin koulukunnan ajatuksissa 1920- ja 1930-luvulla, nähtiin, että 1900-luvun massatuotanto ja massakulutus passivoivat kuluttajan mainonnan propagandan uhriksi. Massojen käsitteen synty kytkettiin urbanisoitumiseen, tehtaiden massatuotantoon ja työläisten joukkoon. Massamarkkinat hajaantuivat, kun teollisuuden ylituotanto aiheutti painetta tuotteiden erilaistamiseen erilaisille kuluttajaryhmille samaan aikaan kun keskiluokan kasvu ja kaupunkiin muutto muuttivat kulutusmahdollisuuksia 1960-luvulla (Arvidsson 2006, 51). Ajatus passiivisista massoista oli 1980-luvun lopulla ja erityisesti 1990-luvulla joutunut kyseenalaistetuksi. Tuolloin painotettiin käsitystä kuluttajasta aktiivisena, yksilöllisenä toimijana, joka toteuttaa itseään ja viestii muille identiteettiään kuluttamalla. (Ks. esim. Cantor 1987 [1976], 367-374; Puustinen 2008, 40-45.) Kuten Raymond Williams totesi, massoja ei ole, vaan vain tapoja nähdä ihmiset sellaisina (Williams 1960 [1958], 317). Vastaavasti yksilöllisen itseään toteuttavan kuluttajan malli kytkeytyi laajempaan taloudelliseen ja kulttuuriseen muutokseen eriytyneisiin makukulttuureihin globalisoituvassa halpatuotannossa.

\section{Myytävät kuluttajaryhmät}

Kuluttajien luokittelussa toiset kuluttajaryhmät ja piirteet arvotetaan mainosmyynnin näkökulmasta arvokkaammiksi kuin toiset. Halutut kohderyhmät määrittävät myös ohjelmistosuunnittelua, kun ohjelmia suunnataan tietyille kohderyhmille. Esimerkiksi 1990-luvun puolivälissä parhaan katseluajan ohjelmapaikkoja uudistettiin erikoistamalla ohjelmatyyppejä suurten yleisöjen ohjelmista erityisesti 25-44-vuotiaille naisja mieskohdeyleisöille. Tv-mittaritutkimuksen ja Monitor-asennetutkimuksen kehittyessä kohderyhmien tarkempi määrittely mahdollistui ja 1980-luvun lopulla massamarkkinoista alettiin siirtyä yhä enemmän kohti kohderyhmien kauppaa. Vuodesta 1992 mediaoppaissa puhuttiin kohderyhmäkaupasta, jossa halutun kohderyhmän tavoittamiselle sai kampanjassa kontaktitakuun. Tällöin mainostaja ei maksanut "turhista kontakteista". Ajatus vääristä katsojista syntyi jo 1980-luvun puolivälissä media- 
toimistoissa, mikä vaikutti suurten yleisöjen suosikkien kuten Lauantaitanssien lopettamiseen vuonna 1987. (Kannisto 2015, 57-58.) Tarkastelen seuraavaksi MTV:n mainosmyynnissä esiin nostettuja ja arvotettuja kuluttajaryhmiä: nuoret ja nuoret aikuiset, perheenemännät, lapsiperheet, kaupunkilaiset ja päättäjät. Pohdin myös näiden ryhmien kulutusedellytyksiä 1990-luvulla.

\section{Nuoret ja nuoret aikuiset}

"Nuorille 9o-luvun televisio" (Äijälä 1989, 37), määritteli ohjelmajohtaja Tauno Äijälä MTV-kanavan ohjelmapolitiikan yhdeksi painoalueeksi MTV:n viestintäseminaarissa 1989. Kaapeli- ja satelliittikanavien - etenkin Sky Channelin ja Music TV:n - tarjonta lapsille ja nuorille lisäsi heidän television katseluaan ja tarjosi mainostajille uuden tarkemman kohderyhmän 1980-luvun loppupuolella (ks. esim. Kortti 2007a, 150-152). Nuorille suunnattu tarjonta lisääntyi myös MTV:Ilä 1990-luvulla. MTV:Ilä syksyllä 1990 alkanutta populaarikulttuurin ajankohtaisohjelma NO TV:tä markkinoitiin mainostajalle uudenlaisena nuoret tavoittavana kotiinpaluuohjelmana (klo 17-19): "Nopeasykkeisenä ja uudentyyppisenä ohjelmana NO TV löysi muutamassa viikossa yleisönsä - kriittisesti kuluttavat nuoret aikuiset" (MM kevät 1991, TYK, 18).

Mediaoppaissa luokitelluiksi ikäryhmiksi vakiintuivat: 3-14-vuotiaat, 15-24-vuotiaat, 25-34-vuotiaat, 35-44-vuotiaat, 45-65-vuotiaat ja yli 65-vuotiaat. 15-24-vuotiaiden kohderyhmän piirteiksi yhdistettiin mediaoppaissa "liikkuvat ja aktiiviset" ( $M M$ kevät 1994, TYK, 7) ja "trendejä seuraavat" (SyysManager 2000, TYK, 3). SyysManagerin mukaan nuoret etsivät ulkomaisista sarjoista mm. kampaus- ja meikkaustyylejä ollakseen trendikkäitä. Monitor-typologioiden ryhmistä nautiskelevissa materialisteissa ja empaattisissa riskinottajissa korostuivat alle 24-vuotiaat, joita kuvailtiin edelläkävijöiksi ja nopeiksi uusien asioiden omaksujiksi (MM 1991/2, TYK, 9). Omaksujatyypit olivat tärkeitä kuluttajaluokitteluja: MTV:Ilä viidelle omaksujatyypille edelläkävijöistä vitkastelijoihin määriteltiin suosikkiohjelmia, joiden yhteyteen mainontaa sijoittaa. Monitoroppaan mukaan edelläkävijät tavoitti esimerkiksi Miami Vicen (USA 1984-1989) parista, mikä sopii lanseerausmainontaan hyvin. Kampanjan edetessä sopivia ohjelmia löytyi omaksuja-akselin eri kohdilta. (MTV 1989, TYK, 1, 4.) Nuoruus ja uuden omaksuminen kytkettiin yhteen, vanhempien uskottiin vakiintuneen kulutustavoiltaan. Nuorille kulutuksella ilmaistava elämäntyyli oli avainasemassa identiteetin rakentajana, jolloin heidät nähtiin erityisen vastaanottavaisina mainonnalle (Miles 2000, 154).

Nuoruus itsessään on tulkinnanvarainen käsite, jonka sisältö on sidoksissa lähestymistapaan. Nuoren ihmisen yläikärajana on pidetty 20-34 vuotta. (Autio 2006, 17.) Markkinoinnissa kohderyhmänä ovat nuorten 15-24-vuotiaiden lisäksi myös 25-44-vuotiaat nuoret aikuiset, joille kohdennetaan eniten mainontaa (Puustinen 2008, 162-170). Useissa tulkinnoissa esitetään, että yhtenäisten nuorisokulttuurien maailmassa kasvanut sodanjälkeinen sukupolvi, eli suuret ikäluokat, ikään kuin kieltäytyivät kasvamasta aikuisiksi ja toivat keski-ikäisyyteensä voimakkaasti nuorekkuutta korostavan arvomaailman ja kulutustavat. Koska suurilla ikäluokilla oli ja on edelleen suurimmat kulutusmahdollisuudet, myös markkinat alkoivat pyöriä nuoruuden ja nuorekkuuden 
ympärillä. "Aikuisuus" sai kielteisen sivumerkityksen mainonnassa ja kulttuurissa yleisemminkin. (Napoli 2003, 104-105; Wilska 2001, 64.) Mainonnassa tuotetaan nuoruuden ihannointia ja kohderyhmien implisiittistä hierarkiaa: toiset kohderyhmät ovat haluttavampia kuin toiset. (Puustinen 2008, 291-292.) MTV:Ilä mainosmyynnin hintoihin vaikutti suoraan kohderyhmän koko ja tavoittavuus. Kohderyhmähinnaston esimerkissä pienin kohderyhmä 15-24-vuotiaat oli kallein, kun taas isoin kohderyhmä päivittäistavaraostoista vastaavat oli halvin kontaktihintaa määriteltäessä ( $M M$ 1/96, TYK, 19). Suomalaista nuorta kuluttajaa rakennettiin markkinoinnin kohderyhmänä aktiivisesti 1960-luvulta lähtien, mutta etenkin käytettävissä olevien tulojen näkökulmasta nuoret nousivat tärkeäksi kohderyhmäksi vasta 1990-luvulla kuluttamalla enemmän kuin muut ikäryhmät. Sen lisäksi että nuorten ostovoima oli parantunut, heillä oli vaikutusta myös perheen yhteisiin ostopäätöksiin. (Autio 2006, 18; Wilska 2001, 61.)

\section{Perheenemännät - kuluttajan sukupuoli}

Nuorista poiketen 25-44-vuotiaat oli MTV:n luokittelussa jaettu sukupuolen mukaan eri kohderyhmiksi. Miehille ja naisille määriteltiin erilaiset suosikkiohjelmat ja katsomistavat, esimerkiksi "[k]un mieshormoonit oikein jylläävät kehossa on toiminnan aika - tai sen katsomisen" ja "[n]aiset ovat uskollisia lempiohjelmilleen ja myös päivittäisille sarjoille" (SyysManager 2000, TYK, 8, 14). län ja sukupuolen yhdistävässä luokittelussa pyritään rakentamaan yhtenäistä ryhmää, jolla olisi tietty kuluttamisen tapa. Sukupuolen vaikutus markkinointiin riippuu mainostettavista tuotteista, mainosmyynnissä tehtävänä on kuvailla, kuinka iso osa kohderyhmästä ja kuinka uskollisesti kohderyhmä tavoitetaan tiettyjen ohjelmien avulla.

Luokitteluissa tärkeä ryhmä olivat myös perheenemännät (PEM), johon 1990-luvulla MTV:n markkinoinnissa alettiin viitata nimellä päivittäistavaraostoista vastaavat. Alkuperäinen nimitys perheenemännistä kytkee ryhmän oletukseen naisesta äitinä, joka tekee kotitalouden ostopäätökset koko perheen puolesta. Päivittäistavaramainonnassa naiset nähdään suurimpana asiakasryhmänä ja päivittäistavaraa mainostetaan eniten televisiossa. Puustisen tutkimuksen mukaan mainonnan ammattilaisille 25-44-vuotiaiden naisten kulutusintensiivinen joukko on ihanteellisin kuluttajaryhmä, jolle suurin osa mainonnasta on kohdennettu (Puustinen 2008, 165, 172-181.). Kulutuksen aluetta on historiallisesti luonnehdittu feminiiniseksi ja länsimaisen kulutuksen kehityksessä feminiininen - arvaamaton ja hedonistinen - on merkitty prototyyppiseksi kuluttajaksi (ks. esim. Cronin 2005 [2000], 38; Friedberg 1993; Kortti 2007b, 108-111).

\section{Lapsiperheet}

Lapsiperheet nostetaan erityisenä kuluttajatyyppinä esiin kohderyhmäluokitteluissa: Monitor-typologiana turvallisuushakuiset perheihmiset ja erillisissä luokitteluissa perhekoon tai elinvaiheen mukaan. Esimerkiksi elinvaihe 4 tarkoittaa nuoria lapsi- 
perheitä eli 18-44-vuotiaita, joiden lapset ovat o-6-vuotiaita. Mainostajille kiinnostavimmaksi nostetaankin nuori perhe (SyysManager 2000, TYK, 16). Kuluttajina heitä määritellään järkeviksi ja turvallisuushakuisiksi ja heidät tavoittaa hyvin, etenkin lauantaisin MTV:n lasten- ja perheohjelmiston parista: "Lapsiperheet ovat ahneita uutuuksille, vaikka eivät varsinaisia edelläkävijöitä olekaan. Perheihmiset etsivät tukea valinnoilleen. Tutut tuotemerkit merkitsevät heille turvallisuutta. Tv:n ääressä he rentoutuvat ja saavat tietoa ulkomaailmasta." (MM 2 /1990, TYK, 12; MM 2/1991, TYK, 9.) Mainonnan menestyneitä ratkaisuja esittelevässä oppaassa lapsiperheille suunnattuja tuotteita edustivat Citymarket ja Oltermanni, joiden mainoskampanjat oli suunnattu koko kansalle ja tavallisille ihmisille. (Mainostajan ratkaisut, 1998, TYK, 17-18.)

Päivittäistavarakaupan ja kotona tapahtuvaan kulutukseen liittyvät mainostajat ovat kiinnostuneita suuntamaan tuotteitaan lapsiperheille, joiden kulutus on suurempaa kuin lapsettomalla pariskunnalla (Raijas 2013). Vuonna 1985 kolme eniten kuluttavaa ryhmää olivat lapsettomat parit sekä kahden ja yhden huoltajan lapsiperheet. 1990-luvun laman jälkeisellä nousukaudella kaikkien kotitaloustyyppien reaaliset kulutusmenot ovat nousseet, 2000-luvun alussa erityisesti kahden huoltajan lapsiperheet ja eläkeikäisten taloudet ovat pystyneet lisäämään kulutustaan. (SVT 2006.) Kapitalistinen kulttuuri on suosinut ydinperheen mallia normina ja ihanteena teollisen aikakauden alusta, koska siihen kytkeytyy runsaasti ostovoimaa (Puustinen 2005, 56). Ostovoiman lisäksi perheet edustavat kuluttajamielikuvissa tavallisuutta, yhtenäistä joukkoa, joka turvallisuushakuisuudessaan toimii niin kulutuksen kuin yhteiskunnan perustana. Myös mainoksissa perhenormina esitetään turvallinen keskiluokkainen ydinperhe (Kortti 2003, 263-264).

\section{Kaupunkilaiset}

MTV:n kohderyhmäluokitteluissa yhtenä luokitteluna ovat suurkaupungeissa asuvat ja erikseen suur-helsinkiläiset. Asuinpaikka on vanhimpia kuluttajien luokitteluja, sillä alueellisuus on merkittävä kohderyhmän määrittelijä esimerkiksi kaupoille, jotka haluavat tavoittaa oman alueensa kuluttajat. Kaupungeissa ostovoima on suurin ja kaupungeista suur-Helsingin kohderyhmän koko on Suomen suurin. Tilastoidun ostovoiman lisäksi mainonnan ammattilaiset tuottavat vahvasti stereotypisoivaan mielikuvaan pohjautuvaa erottelua pääkaupunkiseudun ja muun Suomen välillä. Urbaanit cityihmiset ovat pääkaupunkilaisia, joiden kulutus eroaa muun Suomen ja lähiöihmisten kulutustavoista. (Puustinen 2008, 149-150.)

Kaupunkilaiseen kulutukseen yhdistetään mielikuvia, esimerkiksi aktiivinen, dynaaminen, trendikäs ja kiireinen (Puustinen 2008, 149). Aktiivisuuden kuvaa tukee MTV:n tutkimus, jossa kerrotaan, että kokonaisuudessaan kaupunkilaisten osuus kasvaa ohjelmien katsojakunnassa keski-illasta myöhäisiltaa kohden (Tutkimus 1997, TYK, 30). Tuolloin MTV alkoi ohjelmasijoittelussa strategisesti panostaa myös erityisyleisöjen myöhäisiltaan (Kannisto 2015, 57). Vastaavasti vuonna 1997 aloittanut kilpaileva kaupallinen kanava Nelonen määritteli toimintansa alussa kohderyhmänsä 
ennen kaikkea nuoren iän ja kaupunkilaisuuden perusteella, mutta myös psykografisiin ominaisuuksiin perustuva kohderyhmämäärittely, ennakkoluulottomat ja uteliaat aktiiviset aikuiset, liitettiin kanavan markkinoinnissa katsojiin (Kaarlela 2004, 36-37). Mielikuva kaupunkilaiskuluttajasta oli jatkoa 1980-luvulla nousseelle sinkkuja juppikulutukselle, jolla tarkoitettiin nuorten aikuisten näyttävää, kaupunkimaista kulutustyyliä. Yksin asuvat kaupunkilaisnuoret yhdistettiin edelläkävijyyteen uusien kulutustapojen omaksumisessa. (SVT 2006.) Kuluttaminen alettiin nähdä keskeisenä käyttäytymistapana, jolla liitytään kaupunkitilaan ja toisiin ihmisiin ja jolla kaupunkiin liitetään sosiaalisia merkityksiä (ks. esim. Tuovinen 1993, 95-96).

\section{Päättäjät}

Päättäjät ovat mukana näkyvänä kohderyhmänä koko 1990-luvun, kun MTV yhdisti tv-mittaritutkimukseen Suomen Gallup-Media Oy:n tekemän Päättäjien mediatutkimuksen (PMT) keväällä 1991 (MM kevät 1990, TYK, 8). Tutkimuksessa seurataan yritys- ja julkisen sektorin päättäjien eli keski- ja ylimmän johdon mediakäyttöä (TT 1997, 13). PMT:ssa päättäjät voidaan jakaa ryhmiin esimerkiksi organisaatioaseman, toiminta-alueen tai päätöksenteon kohteen mukaan, esimerkiksi atk-laitteiden hankinnasta vastaavat päättäjät, joille voidaan kohdentaa mainontaa heidän seuraamiensa ohjelmien yhteyteen (MM kevät 1992, TYK, 14-15). Monitor-typologioita kuvaavien kuluttajatyyppien ammattinimikkeissä korostuu johdon osuus: kuluttajatyypeissä päälliköiksi on nimetty ryhmät, jotka edustavat 53 prosenttia suomalaisista, vaikka tilastokeskuksen mukaan ylempiä toimihenkilöitä vuonna 1990 oli 18 prosenttia palkansaajista (Lehto \& Sutela 2008, 12). Päättäjien ryhmään yhdistetään mediaoppaassa tehokkuus ja toisaalta tuodaan esille, että päättäjäkin on ihminen, jonka tavoittaa kotoa perheen parista loppuiltaisin. Mainostajalle tämä ryhmä on kiinnostava, koska tilastojen mukaan ylemmät toimihenkilöt kuluttavat eniten suhteessa keskimääräiseen kulutukseen (SVT 2006). Yksityisen kulutuksen lisäksi päättäjät ovat kiinnostavia Business-to-Business-markkinoijan näkökulmasta.

Tuloluokka on yksi vanhimmista ja tärkeimmistä kuluttajien demografisen segmentoinnin käytännöistä (Napoli 2003, 105-106; Puustinen 2008, 145). 1900-luvun alkupuolen markkinoinnissa kuluttajat ryhmiteltiin tulojen mukaan, maun ja siten kulutuksen ajateltiin olevan suoraan luokkasidonnainen (Arvidsson 2006, 49-50). Luokittelussa päättäjät ja ylemmät toimihenkilöt on usein yhdistetty samaan ryhmään. Kulutuksen suhteen toimihenkilötaloudet kykenivät kasvattamaan kulutusmenojaan yrittäjätalouksien rinnalla muita ryhmiä enemmän 1990-luvun puolivälistä uuden vuosituhannen alkuun ulottuvalla jaksolla. Sosioekonomisen aseman ja kotitalouden rakenteen suhteen tarkasteltuna Suomeen on muodostunut kolme kulutukseltaan eriytynyttä ryhmää. Korkean kulutuksen ryhmään kuuluu ylempien toimihenkilöiden ja yrittäjien talouksia sekä lapsettomia pareja ja kahden huoltajan lapsiperheitä. Kulutuksen keskiluokan muodostavat alempien toimihenkilöiden, työntekijöiden ja maatalousyrittäjien sekä yksinasuvien taloudet. Matalan kulutustason ryhmään kuuluu työttömien, opiskelijoiden, eläkeläisten sekä yksinhuolta- 
jien talouksia. Tuloerot kaventuivat Suomessa 1960-luvulta lähtien aina 1990-luvulle asti. Samanaikaisesti myös kulutuserot supistuivat. Tuloerot samoin kuin kulutuserotkin alkoivat kasvaa 1990-luvun puolivälin jälkeen ja ne ovat jatkaneet kasvuaan 2000-luvulla. Lisääntyneen kulutuksen myötä väestöryhmien väliset kulutuserot ovat kasvaneet etenkin 1990-luvun puolivälin jälkeen. (SVT 2006.) Markkinoinnin luokitteluissa korkean kulutuksen ryhmä painottuu, sen sijaan matalan kulutuksen ryhmä jää näkymättömäksi kuluttajaluokitteluissa - he eivät sovi kaupattavaksi kuluttajatuotteeksi.

Edellä kuvatut kuluttajatyypit rakentavat mielikuvia ihanteellisista kuluttajaryhmistä. 1990-luvulla tutkimukset osoittivat, että demografiset tekijät kertoivat huonosti kulutustottumuksista, joten mainostajat eivät enää luottaneet vain niihin mainosvalintaa tehdessään (Napoli 2003, 107; Puustinen 2005, 53). MTV:n mainosmyynnissä demografisiin luokitteluihin yhdistettiin elämäntyyliin liittyviä kuvailuja ja merkityksiä aktiivisesta ja ostovoimaisesta edelläkävijästä - demografisiin ryhmiin yhdistettiin elämäntavan kuvailua. Markkinoinnin diskurssin vaikutus luokitteluihin rajasi ulkopuolelle ristiriitaiset ja taloudellisesti negatiiviset piirteet; yksilöllistä kuluttajaa luokiteltiin ja tuotettiin mielikuvallisesti eri mainostajien intressien mukaan kiinnostavaksi tuotteeksi. MTV:n markkinoinnissa ryhmiä ei voitu rajata vain demografisilla luokitteluilla, vaan mainostajalle tarjottiin mielikuvia kuluttajatyyppien elämäntavasta ja heihin kytkeytyneistä kulutusmyönteisistä ominaisuuksista. Kuten Heikki Kasari totesi jo 1983 raportissaan elämäntyylikuvaajista, demografiat olivat toisensa poissulkevia luokkia, jotka erottelivat kuluttajia enemmän kuin pehmeiden muuttujien elämäntyyliryhmät (Kasari 1983, 18). Roos puolestaan toteaa elämäntapatutkimusta hahmottaessaan, että toisin kuin nykyään, sata vuotta sitten ihmisten luokka-asema, asuinpaikka ja ammatti kertoivat suoraan, miten he elivät. Sitten laskeutui julkisen ja yksityisen elämän välinen verho. (Roos 1986, 39.)

\section{Merkintekijä - brändien ja arvojen immateriaalinen kauppa}

Brändi-diskurssi nousi 1990-luvun mittaan MTV:n markkinoinnissa yhä merkittävämpään rooliin. Brändiajattelun tuoreesta rantautumisesta Suomeen kertoi sanaston muuntuminen; aluksi puhuttiin merkin tekemisestä, sitten brandista, brändi-sana ei ehdi vakiintua vielä vuoteen 2000 mennessä. Merkintekijä-termi ilmaantui markkinointimateriaaliin syksyllä 1992: "Hyvän Idean paras media. MTV. Merkintekijä ennen muita." (MM 2 /1992, TYK, 3). Myynnin ja merkin tekeminen nostettiin mediaoppaassa mediavuoden 1995 pääteemaksi (Media Manager 1/1995, TYK, 4) ja vuodesta 1996 brändit tulivat osaksi tutkimusta - brändien vaaliminen tuli keskeiseksi markkinointitavoitteeksi. Tutkimuksen rooli brändin systemaattiselle rakentamiselle nousi tärkeäksi (Tutkimus Manager, syksy 1996, TYK, 72). Vuoden 1997 Alma Media Oy:n vuosikertomuksessa todettiin, että televisiomainonnan kaupankäynnissä oltiin siirtymässä entistä enemmän mainosajan myynnistä markkinoinnin kokonaispalvelun myyntiin. Tällä viitattiin yksilöllisiin tutkimuspalveluihin, joilla voitiin selvittää mainonnan vai- 
kutusta yleensä ja erityisesti brändien tunnettuutta ja markkina-asemaa, kuten MTV:n vuonna 1996 käyttöön ottama Brand Dynamics -tutkimus.

MTV panosti myös omaan brändiinsä osana markkinointia. Vuonna 1997 MTV3:n brändi oli Suomen vetovoimaisin viestintäbrändi ja kaikista Suomen brändeistä neljännellä sijalla. (Alma Media, vuosikertomus 1997, TÄK, 20.) Siinä missä mainostajalle myytiin erilaisia bränditutkimuksia, myös MTV:n brändi oli immateriaalista pääomaa kaupattavaksi. Brändit ovat mekanismi, jolla kulutus sidotaan osaksi tuotantoprosessiin (Arvidsson 2006, 94), joten myös MTV tuotti aktiivisesti myönteisiä mielikuvia menestyvästä kanavasta mainostajalle kulutettavaksi.

Sponsorointi toimii samalla mekanismilla kuin brändit: tuotteeseen yhdistetään mielikuvia ja käsityksiä elämäntavasta. Sponsoroinnissa televisioidun mediatapahtuman tai mediahahmon imago yhdistetään tuotteeseen. Pelkän mainostilan sijaan MTV myi tietynlaista mediaympäristöä ja ideaa sen kuluttajista. Television alkuaikoina kustannetut ohjelmat olivat olleet tärkeä osa ohjelmistoa ja välttämätön tuotantotapa, mutta ne lopetettiin vuonna 1966, jolloin ohjelmatuotanto siirtyi MainosTV:Ile ja mainosmyyntiä pystyttiin tehostamaan (Kortti 2003, 38). Sponsorointi sallittiin uudelleen ja alkoi MTV3:Ila maaliskuussa 1993. Ensimmäisten sponsoroitujen ohjelmien joukossa olivat urheiluohjelmat, kuten Ruutulippu (Esso/Ultra Synthetic Oil), Formula 1 -lähetykset (Sinebrychoff/Koff 1) ja jääkiekon SM-liiga (Unilever/Axe, Shell/Helix). Sponsorointia kuvailtiin mainostajalle keinoksi luoda yhteys tuotteen ja televisio-ohjelman välille: "Sponsorina voit tarjota omalle kohderyhmällesi sen lempiohjelmia ja saada samalla yrityksellesi poikkeuksellista näkyvyyttä mieluisassa ympäristössä" (MM 3/1994, TYK, 16).

MTV:n markkinoinnissa brändeille haluttiin rakentaa persoonaa kuin ihmisille: "Tee merkistä persoona!" (MM kevät 1995, TYK, 5). Mediaopas vakuutti televisiomainoksen vetoavan tunteisiin paremmin kuin muut mediat. Brändien persoonat sulautuivat mediaoppaiden käyttämissä diskursseissa kuluttajatyyppien personointiin, ja tuotteiden persoonia tutkittiin kuin katsojia. Tuotteen markkinointi ja kuluttajan myynti kulkevat rinnakkain, massamyynnistä persoonallisiin brändeihin. Tavaramerkin käyttämisen voi katsoa alkaneen jo vaihdantatalouden syntymisen ajoilta, kun tuote haluttiin yksilöidä muista samaa tarvetta palvelevista tuotteista. Merkkitavarakauppa $^{2}$ sai $1800-$ ja $1900-l u v u n$ vaihteessa uudenlaisen merkityksen, kun yksittäistuotannosta siirryttiin tuotesarjojen valmistukseen ja pakkausten käyttöönotto ja sanomalehti-ilmoittelun aloittaminen mahdollistivat mainonnan nykyaikaisessa mielessä. (Kaskimies 1970 [1958], 9-12.) J. P. Roos kytkee 1900-luvun suomalaista elämäntapaa hahmotellessaan merkkitavarakulttuurin uuden keskiluokan kulutuskulttuuriksi, kun taas massakulttuuri kuului rahvaalle (Roos 1986, 54). Merkkitavarat ovat erottautumisen välineitä, joiden avulla viestitään identiteetistä kulutuksen kautta.

Nuoret liitettiin 1990-luvulla uudella tavalla brändeihin, joiden merkitys markkinoinnissa oli kasvussa. Myös suomalaiset alkoivat ostaa kansainvälisiä merkkituotteita kasvavissa määrin. Merkkimainonnan osuus kaikesta mainonnasta oli kaksi kolmannesta 1990-luvun alkupuoliskolla (Heinonen \& Konttinen 2001, 280). Syksyn 
1995 MTV:n Media Managerissa todettiin brändien olevan tärkeitä nuorille ja nuorten osaavan merkkikielen, kun "[K]ansainvälistyminen ja monikansallisten merkkien yleistyminen nostaa merkit keskeiselle sijalle nuorten maailmankuvassa" ( $M M$ 3/95, TYK, 5). Arvidssonin mukaan 1990-luvun nuorten X-sukupolvi nähtiin epävarmuudessa kasvaneina pysyvien järjestelmien ja uskomusten epäilijöinä, joille brändit täyttivät perinteisten arvojen ja yhteisöjen murtumisen jättämää tyhjyyttä (Arvidsson 2006, 83). Brändejä tutkineen Alissa Quartin mukaan markkinoinnilla ja mainoskampanjoilla on suuri merkitys nuorten elämässä, koska he ovat sekä tuotteiden ostajia että nuoria, jotka pitävät imagoaan ikään kuin brändinä. Sosiaalista identiteettiä rakennetaan kuluttamalla, oman tyylin kautta. Omaan itseen halutaan liittää kuluttamalla tietynlaisia mielikuvia, joiden lähteenä usein on mainonta ja markkinointi, tuotteiden brändit. (Quart 2003, 24-25.) Syksyllä 1995 MTV3:Ila aloitti nuorten kohderyhmälle kehitetty ohjelmakonsepti Jyrki, joka mainosmyynnin kuvauksessa oli "uusi, aivan omanlaisensa ja omannäköisensä ohjelmatuote, tutkittu ja testattu paketti jolla vihdoin tulet tavoittamaan ne 12-35-vuotiaat, jotka tähän asti ovat usein livahtaneet medioiden välistä" (MM 3/95, TYK, 34). Jyrki oli osa "tehopanostusta nuorisoon", jonka avulla $M_{T V}$ :sta rakennettiin kohderyhmämediaa nuorille (MM 1/96, TYK, 4).

Kulutustutkija Visa Heinosen mukaan nuoriso oli tullut itsenäiseksi mainonnan kohderyhmäksi jo 1960-luvulla, kun nuorten kulutustottumukset laajentuivat ja uudenlainen muotitietoisuus rantautui maailmalta Suomeenkin (Heinonen 2003). Nuorille markkinoitiin ennen kaikkea vapaa-ajan tuotteita ja viihdettä (Miles 2000, 107-109). 1980-luvulla mainostajat halusivat kasvavissa määrin suunnata myös muiden kuin erillisten nuorisotuotteiden kampanjoita nuorille. Esimerkiksi Valio halusi nuorentaa maidon mielikuvaa 1980-luvulla, jolloin "Milky energy" -kampanjassa mukailtiin Coca Colan mainontaa (Heinonen \& Konttinen 2001, 223). Sosiologi Steven Miles kuvaa muutosta, kuinka ennemmin maku kuin ikä tuli nuorisokulttuuria määrittäväksi tekijäksi, ja nuoruus alkoi merkitä ikäryhmän sijaan elämäntapaa. Nopeassa yhteiskunnallisessa muutoksessa kulutus mahdollistaa joustavan identiteetin ja toisaalta jatkuvuuden muutoksessa. Nuoruus luo kulutukselle ympäristön, jossa mikä tahansa on mahdollista. (Miles 2000, 123-124, 154-159.)

\section{Lopuksi - potentiaalin politiikka}

Kun televisioyhtiö luokittelee kuluttajia erilaisiksi tuotteiksi mainostajalle, se rakentaa mahdollisuusdiskurssia, joka suuntautuu ikuisesti tulevaisuuteen, tuotteisiin jotka voivat tulla ostetuksi. Kuluttajaa hahmotetaan kuluttajan mahdollisuuksia jäsentävän ihanteellisen yhtenäisen identiteetin avulla. Markkinoinnissa MTV koetti puuttua kuvitteellisten mahdollisuuksien ja kuluttajan identiteettipolitiikan piiriin ja sulauttaa brändit yksilön kuvitteellisiin elämäkerrallisiin liikkeisiin. (Cronin 2005 [2000], 40-49.) Kuluttajatyyppien kuvailussa ja luokitteluissa MTV rakensi potentiaalista kuluttajaa, jolle mainostajat haluavat myydä tuotteitaan. Jos mainostajalle 
myyty kuluttajapotentiaali rakentuu suhteessa mainonnan tarjoamaan kuluttajapositioon, on syytä pohtia, tarjotaanko ja suunnitellaanko tuotteita ja palveluita ihanneryhmien ulkopuolisille? Potentiaali - mahdollinen kuluttaja alkaa määrittää "todellista" kuluttajaa markkinoilla.

Televisioyhtiö rakentaa potentiaaliselle kuluttajalle yhtenäistä identiteettiä markkinointitutkimuksen avulla. RISC Monitor -tutkimus oli vahvassa asemassa MTV:Ilä ja laajemmin mediataloissa, koska se tarjosi niiden käyttöön pitkälle tuotteistettuja tietoja kuluttajista monipuolisine sovelluksineen ja oheispalveluineen. Monitor-tutkimusta on kritisoitu siitä, että arvo- ja asenneulottuvuudet ovat empiirisiä yleistyksiä ilman selkeitä teoreettisia lähtökohtia. Pertti Suhonen arvostelee Monitor-tutkimuksen luotettavuutta siitä, että asennetypologia on pitkälle menevä yleistys ihmisten asenteista ja niiden välisistä kytkennöistä. Asenneryhmien esittämisen tapa antaa vaikutelman selvärajaisista ryhmistä, vaikka suuri osa ihmisistä kasautuu keinotekoisille ryhmärajoille, jotka jakavat asenteiltaan jokseenkin samanlaisia ihmisiä. Ryhmien kokojen muutokset kertovatkin siten vain vähäisistä asenteellisista liikahduksista. Lisäksi Suhonen nostaa esiin, kuinka RISC ei vain ennakoi muutosta vaan vauhdittaa sitä, kun suuret mediatalot, mainostoimistot, yritykset, talouselämä, etujärjestöt ja julkinen sektori ottavat huomioon samat tutkimustulokset ja toimivat niiden mukaisesti. RISC ei vain mittaa asenteita, vaan tuloksillaan ohjaa julkista ilmapiiriä ja muuttaa asenteita. (Suhonen 2002, 153-154, 157, 159-161.)

Potentiaalinen kuluttaja vaikuttaa suoraan myös MTV:n ohjelmasuunnitteluun. Ohjelmistoa suunnitellaan, hankitaan ja sijoitetaan arvostetuimpien yleisösegmenttien houkuttelemiseksi. Usein vähiten kiinnostavat yleisösegmentit, joille MTV suuntaa vähiten tarjontaa, kuitenkin kuluttavat televisiota eniten. Samaan aikaan kun televisiotarjonta on lisääntynyt, on myös katsojatutkimus kehittynyt teknologisesti niin, että entistä tarkempi kohdentaminen on mahdollistunut. Näin katsojien luokittelu ja arvottaminen on saanut enemmän valtaa mediayhtiöiden toiminnassa ja lisääntynyt tarjonta on entistä tarkemmin suunnattu tietyille arvostetuille kohderyhmille. (Ks. esim. Napoli 2003, 96-97.) MTV:n ohjelmasijoittelussa arvostettujen yleisösegmenttien tavoittelu on näkynyt muun muassa lauantai-illan ohjelmistossa. Lauantai-ilta oli legendaarinen MTV:n viihteen ikkuna 1970-luvulta 1990-luvulle, mutta 1990-luvun lopulla mainostajat kaikkosivat, kun ajateltiin, etteivät tavoitellut aktiiviset kuluttajat katso silloin kotona televisiota. Koska mainostajat ovat menettäneet kiinnostustaan lauantai-illan ohjelmapaikkaan, ei MTV:n kannata panostaa siihen, vaikka suuret yleisöt, jotka mielletään vanhoiksi ja ei-kiinnostaviksi mainostajien taholta, edelleen katsovat silloin televisiota. (Kannisto 2015.)

1990-luvulla käyttöönotetut kuluttajatyypit ja kohderyhmät näkyvät edelleen tämän päivän markkinoinnissa. Kiinnostavimpia kohderyhmiä yhdisti 1990-luvulla hyvän ostovoiman lisäksi nuoruus, edelläkävijyys ja aktiivisuus, jotka liitettiin ihanteelliseen kulutukseen. Vaikka nuoret eivät välttämättä olleet todellisuudessa kaikkein suurin kuluttajaryhmä, brändien nousu markkinoinnissa nosti heidät mainostajia kiinnostavaksi uusia tuotteita omaksuvaksi ryhmäksi. MTV:n markkinoinnissa käytettiin kuluttajan kuvailussa demografisia luokitteluja iästä, sukupuolesta, asuinpaikasta, 
ammattiryhmistä ja elämänvaiheesta. Luokittelujen ulkopuolelle jäi esimerkiksi koulutustausta, joka taas sosiologisissa luokkamäärittelyissä yleensä on nähty keskeisenä. Kuluttajatyyppien luokkasidoksessa olisi aihetta jatkotutkimukselle.

Laman konteksti näkyi markkinoinnissa 1990-luvulla, kun tehokkuutta alettiin korostetusti nostaa esiin ja arvostaa mainosmyynnissä vähenevien mainosbudjettien myötä. 1990-luvun mediaoppaissa näkyy muutos retorisempaan suuntaan 1980luvun demografisten taulukoiden ja hinnastojen jälkeen, kun markkinoinnissa kilpailun kiristyessä ja kuluttajan yksilöityessä tuli tarve mielikuvallisempaan ilmaisuun. Mäenpää toteaa, että 1990-luvun alun lama teki ilmeiseksi sen, kuinka kaikki eivät voi kuluttaa, vaikka haluaisivat. Lamasta seurasivat joukkotyöttömyys ja pätkätöiden epävarma arki. Kulutuksesta puhuttiin positiivisena arvona ja kansantalouden nostajana, jolla turvattaisiin Suomeen työpaikkoja. Mäenpää tulkitsee, että työelämässä ja kuluttamisessa läpikäytiin samanlainen murros, jonka seurauksena elämäntapa oli korostetummin yksilöllinen valinta ja kuluttaminen elämäntavan ilmaisemista ja tuottamista. (Mäenpää 2004, 302, 308-309.) Suomalaisten suhtautuminen mainontaan muuttui myös laman myötä: laman aikaan 1990-luvun alussa se oli kielteisimmillään, 1990-luvun puolivälissä suhde mainontaan ja kuluttamiseen muuttui asenteeksi, että nyt on taas lupa nauttia elämästä ja shoppailusta (Heinonen \& Konttinen 2001, 295).

1990-luvulla markkinoinnissa korostettiin kuluttajien aktiivisuutta ja asiakaslähtöisyyttä. Yksilökeskeisyyden ja vastuun antamaa kuluttajien markkinavaltaa on laajasti kritisoitu näennäiseksi, koska kuluttajatutkimukset eivät tutki sitä, mitä kuluttajat haluavat tai vaativat tuotteelta, vaan miten markkinointi onnistuu brändin tuottavuuden rakentamisessa. Kuluttajien luokittelu toimiikin hallinnan välineenä, jossa katsojatutkimuksen tiedon avulla määritellään ihmisiä sen mukaan, mitä heiltä halutaan. Katsojien rakentaminen myytäviksi tuotteiksi asettaa kuluttajien maun ja elämäntyylit tiettyihin markkinoinnin tarkoituksiin sopiviin ja kulutusvalintojen määrittämiin kategorioihin. (Maxwell 2000, 104-107.) Kuluttajat ovat median ja mainostajien tarkkailun alaisena, kun heitä halutaan myydä ja ostaa. Markkinoinnin avulla yritykset pyrkivät ohjailemaan kuluttajien toimintaa ja arkielämän rituaaleja siten, että yritysten tuotteille ja palveluille syntyy kysyntää. (Ks. Puustinen 2008, 61-62.) Kuluttajan asema markkinoilla MTV:n tuotteena ja toisaalta mainostajan tuotteiden ostajana voidaan nähdä valtasuhteena, jossa kaikki osapuolet muovaavat, ohjaavat ja rajoittavat toistensa toimintaa ja osallistuvat kulutusyhteiskunnan valtarakenteiden tuottamiseen. Suhde on historiallinen ja kulttuurinen: se on prosessi, joka muotoutuu ja jota muokataan jatkuvasti kulutusyhteiskunnan käytänteissä. Mainosmyynnin arvot muuttuvat hitaammin kuin markkinat ja tilastoitu kulutus - nuoruus myy, vaikka nuoret eivät enää ostaisi. 


\section{Viitteet}

$1 \quad$ Oy Mainos-TV-Reklam Ab muutti nimensä MTV Oy:ksi vuonna 1982. MTV3 aloitti yhtiön omana kanavana 1993. Vuonna 1998 yhtiö siirtyi osaksi Alma Media Oyj:tä. Yhtenäisyyden vuoksi käytän artikkelissa kauttaaltaan MTV-nimitystä yhtiöstä puhuessani.

$2 \quad$ Merkkitavara-termi mainitaan jo vuoden 1932 Mainonnan perusteet -teoksessa.

\section{Alkuperäisaineisto}

Kasari, Heikki (1978). Katsomishalukkuus ja ohjelmatyypit. MTV:n viestintäraportteja, sarja A 1/1978, Oy MainosTV-Reklam Ab.

Kasari, Heikki (1983). Elämäntyylimuuttujat televisioyleisön kuvaajina. MTV:n viestintäraportteja, sarja A 2/1983, Oy Mainos-TV-Reklam Ab.

MDC RISC International Oy (2004). Powerpoint-esitys "Mikä on RISC?". TNS Gallup, RISC Monitor.

MTV (1968). Kaupallinen televisiotoiminta. Oy Mainos-Tv-Reklam Ab:n johtokunnan lausunto Oy. Yleisradio Ab:n hallintoneuvostolle siitä muistiosta, jonka Yleisradion pääjohtajan työryhmä on laatinut televisiomainonnasta.

MTV (1984). Spotti. Tähdellistä tietoa TV-mainonnan tutkimuksesta.

MTV (1989). Monitor - TV-mainosajan ostajan opaskirja.

MTV (1990a). Millaisia ovat suomalaiset television katsojat? Monitor-tietoa mediavalintaa ja mainonnan suunnittelua varten.

MTV (199ob). Miljoonayleisöt ja kontaktitakuu. Tehokas kampanjasyksy MTV:stä.

Tauno Äijälän kokoelma, Helsinki (TÄK) MTV:n vuosikertomuksia ja ohjelmistonsuunnitteluun liittyviä muistioita ja esityksiä 1981-2005.

Turun yliopiston kirjaston pienpainatekokoelma, Raisio (TYK), MTV:n vuosikertomuksia, Media Manager -oppaita (MM) ja markkinointiaineistoa, 1981-2005.

Äijälä Tauno (1989). MTV-kanavan ohjelmapolitiikka. Ohjelmapolitiikka ja viestintäkulttuuri. MTV:n viestintäseminaari 10.10.1989: MTV, 32-38.

\section{Kirjallisuus}

Allardt, Erik (1986). Elämäntapa, harkinta ja muoti ihmisten valintojen perustana. Kymmenen esseetä elämäntavasta, toim. Kalle Heikkinen. Oy Yleisradio Ab, 1986, 1-32.

Ang, len (1991). Desperately Seeking the Audience. London: Routledge.

Arvidsson, Adam (2006). Brands: Meaning and Value in Media Culture. London: Routledge.

Autio, Minna (2006). Kuluttajuuden rakentuminen nuorten kertomuksissa. Helsinki: Suomalaisen Kirjallisuuden Seura.

Autio, Minna \& Wilska, Terhi-Anna (2003). Vihertävät tytöt ja vastuuttomat pojat - nuorten kuluttajien ympäristöasenteet. Nuorisotutkimus 21(2003): 2, 3-18.

Cantor, Muriel (1987 [1976]. Audience Control. Television: The Critical View, toim. Horace Newcomb. New York, Oxford: Oxford University Press.

Cronin, Anne M. (2005 [2000]). Konsumerismin "pakkoyksilöllisyys": naiset, tahto ja mahdollisuus. Lähikuva 2/2005, 37-51.

de Mooij, Marieke (1998). Global Marketing and Advertising. Understanding Cultural Paradoxes. Thousand Oaks, London and New Delhi: Sage Publications.

Fiske, John (1987). Television Culture. London and New York: Routledge.

Friedberg, Anne (1993). Window Shopping: Cinema and the Postmodern. Berkeley : University of California Press.

Heinonen, Visa (2003). Nuoriso mainonnan kohteeksi - kovaa menoa ja meininkiä. Teoksessa: Arkinen kumous. suomalaisen 6o-Iuvun toinen kuva, toim. Matti Peltone, Vesa Kurkela \& Visa Heinonen. Helsinki: Suomalaisen Kirjallisuuden Seura.

Heinonen, Visa \& Konttinen, Hannu (2001). Nyt uutta Suomessa! Suomalaisen mainonnan historia. Helsinki: Mainostajien Liitto. 
Hellman, Heikki (2012). Koko illan ilo? Kolmoskanava ja television kaupallistuminen Suomessa. (Historiallisia Tutkimuksia 258). Helsinki: Suomalaisen Kirjallisuuden Seura.

Hujanen, Taisto (2002). The Power of Schedule. Programme Management in the Transformation of Finnish Public Service Television. Tampere: Tampere University Press.

Kaarlela, Miia (2004) Miten tehdään tv-kanava kohderyhmälle? Nelosen ohjelmisto 1997-2003. Tiedotusopin pro gradu -tutkielma, Tampereen yliopisto. Julkaisematon.

Kannisto, Maiju (2015). Lauantai-ilta MTV:Ilä 1981-2005. Kaupallisen television strategiat ohjelmasijoittelussa. Lähikuva 28:4, 39-66.

Kasari, Heikki J. (1988). Yleisö sähköisen viestinnän muutospaineessa. Helsingin yliopisto, tiedotusopin laitos, julkaisuja 1.A/5/88.

Kaskimies, Mika (1970 [1958]). Merkkitavara nykyajan markkinointimuotona. Liiketaloustieteellisen Tutkimuslaitoksen julkaisuja 23.

Keinonen, Heidi (2011). Kamppailu yleistelevisiosta. TES-TV:n ja Tesvision merkitykset suomalaisessa televisiokulttuurissa 1956-1964. Tampere: Tampere University Press.

Kortti, Jukka (2003). Modernisaatiomurroksen kaupalliset merkit. 6o-luvun suomalainen televisiomainonta. Helsinki: Suomalaisen Kirjallisuuden Seura.

Kortti, Jukka (2007a). Näköradiosta digiboksiin. Suomalaisen television sosiokulttuurinen historia. Helsinki: Gaudeamus.

Kortti, Jukka (2007b). Sukupuoli mainonnan ja mainonnan tutkimuksen historiassa. Teoksessa: Vaikuttamista ja valintoja. Monitieteisiä näkökulmia mainontaan ja kulutukseen, toim. Visa Heinonen \& Jukka Kortti. Helsinki: Gaudeamus.

Lehto, Anna-Maija \& Sutela, Hanna (2008). Työolojen kolme vuosikymmentä. Työolotutkimusten tuloksia 1977-2008. Helsinki: Tilastokeskus.

Lind, Merja (2002). Omnipotentista selviytyjästä epävarmuuden ajan tasapainoilijaksi. Yksilö aikakauslehti Imagen 1990-luvun työttömyyttä ja lamaa koskevassa journalismissa. Teoksessa: Lamakirja. Näkökulmia 1990-luvun talouskriisiin ja sen historiallisiin konteksteihin, toim. Helena Blomberg, Matti Hannikainen \& Pauli Kettunen. Turku: Kirja-Aurora, 341-363.

Liikenne- ja viestintäministeriön julkaisuja (LVM) 26/2002. Mainostava Suomi - Alueellisten mainosmarkkinoiden rakenne.

Maxwell, Richard (2000). Surveillance and other consuming encounters in the informational marketplace. Teoksessa: Consuming Audiences? Production and Reception in Media Research, toim. Ingunn Hagen \& Janet Wasko. Cresskill, New Jersey: Hampton Press, 95-110.

Miles, Steven (2000). Youth Lifestyles in a Changing World. Buckingham and Philadelphia: Open University Press.

Moisander, Johanna (2001). Representation of Green Consumerism: A Constructionist Critique. Acta Universitatis Oeconomicae Helsingiensis, A-185. Helsinki: Helsinki School of Economics and Business Administration.

Mäenpää, Pasi (2004). Kansalaisesta kuluttajaksi. Teoksessa: Suomen kulttuurihistoria 4. Koti, kylä, kaupunki, toim. Kirsi Saarikangas, Pasi Mäenpää \& Minna Sarantola-Weiss. Helsinki: Tammi.

Napoli, Philip M. (2003). Audience Economics: Media Institutions and the Audience Marketplace. New York: Columbia University Press.

Nieminen, Hannu \& Pantti, Mervi (2004). Media markkinoilla. Johdatus joukkoviestintään ja sen tutkimukseen. Helsinki: Loki-Kirjat.

Owen, Bruce M. \& Wildman, Steven S. (1992). Video Economics. Cambridge - London: Harvard University Press.

Partanen, Juha \& IImonen, Kaj (1980). Mainonnan taloudellinen tehtävä kapitalismissa. Teoksessa: Mainonta, talous ja yhteiskunta, toim. Pertti Hemánus. Helsinki: Gaudeamus.

Puustinen, Liisa (2005). "Markkinoiden halutuin kohderyhmä". Sukupuoli ja ikä mainonnan ammattilaisten puheessa. Lähikuva 2/2005, 52-65.

Puustinen, Liisa (2008). Kuluttajamuotti. Kuluttajuuden tuottamisesta mainonnan instituutioissa. Helsinki: Gaudeamus.

Quart, Alissa: Brändätyt. Suom. Taina Juvala. Like, Helsinki 2003.

Raijas, Anu (2013). Yhteisen talouden ristiriidat ja ratkaisut nuorissa lapsiperheissä. Tilastokeskus, Hyvinvointikatsaus 4/2013. Saatavilla http://www.stat.fi/artikkelit/2013/art_2013-12-09_011. html?s=o (luettu 2.6.2016). 
Roos, J. P. (1986). Elämäntapateoriat ja suomalainen elämäntapa. Teoksessa: Kymmenen esseetä elämäntavasta, toim. Kalle Heikkinen. Oy Yleisradio Ab, 1986, 35-76.

Rope, Timo (1992). Markkinointitutkimuksen opas. Helsinki: Mainostajien Liitto.

Salmi, Hannu: Tietoyhteiskunta ja talouskriisi. Informaatioteknologinen näkökulma 1990-luvun lamaan. Teoksessa: Lamakirja, toim. Helena Blomberg, Matti Hannikainen \& Pauli Kettunen. Kirja-Aurora, Turku 2002.

Suhonen, Pertti (2002). RISC-analyysi: Median kartta ja kompassi. Journalismikritiikin vuosikirja 2002, toim. Heikki Heikkilä ja Marjut Helminen. Tiedotustutkimus 25(2002):1, 152-161.

Suomen virallinen tilasto (SVT) (2006). Kotitalouksien kulutus. Katsaus kulutuksen muutoksiin. Helsinki: Tilastokeskus. Saatavilla http://www.stat.fi/til/ktutk/2006/ktutk_2006_2009-06-08_kat_001_ fi.html (luettu 2.6.2016).

Tiedolla tuloksiin. Mediatutkimusten käyttäjän opas (TT 1997). Helsinki: Mainostajien Liitto.

Tuovinen, Pentti (1993). Kaupunkirakenteen symbolit. Teoksessa: Kaupunkikulttuuriin!, toim. Tuukka Haarni \& Liisa Knuuti. Espoo: Yhdyskuntasuunnittelun täydennyskoulutus-keskus, Teknillinen korkeakoulu.

Williams, Raymond (1960 [1958]). Culture Q Society 1780-1950. New York: Anchor Books, Doubleday \& Company, Inc.

Wilska, Terhi-Anna (2001). Tuotteistettu nuoruus kulutusyhteiskunnassa. Teoksessa: Nuori ruumis, toim. Anne Puuronen \& Raili Välimaa. Helsinki: Gaudeamus. 